\title{
Status of Medicinal Plants Diversity and Distribution at Rehabilitated Yamuna and Chambal Ravine land Ecosystems in India
}

\author{
S. Kala ${ }^{1}$, H.R. Meena ${ }^{2}$, I. Rashmi $^{3}$, M. Prabavathi ${ }^{4}$, A.K. Singh ${ }^{5}$ and R.K. Singh ${ }^{6}$ \\ ${ }^{1}$ Scientist (Forestry), ICAR-IISWC-Research Centre, Kota-324 002, Rajasthan, India \\ ${ }^{2}$ Scientist (Horticulture), ICAR-IISWC-Research Centre, Kota-324 002, Rajasthan, India \\ ${ }^{3}$ Scientist (Soils), ICAR-IISWC-Research Centre, Kota-324 002, Rajasthan, India \\ ${ }^{4}$ Scientist (soils), ICAR-IISWC-Research Centre, Bellary-583101, Karnataka, India \\ ${ }^{5}$ Principal Scientist (SWC Engg), ICAR-IISWC-Research Centre, Agra-282002, \\ Uttar Pradesh, India \\ ${ }^{6}$ Principal Scientist (Soils), ICAR-IISWC-Research Centre, Kota-324 002, Rajasthan, India \\ *Corresponding author
}

Ravine ecosystems are highly dynamic and completely deformatted terrain landscape. In these regions, Indigenous plant species are playing significant role in environmental rehabilitation because of their exultant survival and high adaptation to local conditions.

\section{Keywords}

Ravines,

Diversity,

Rehabilitation,

In-situ, Ex-situ

Conservation.

Article Info

Accepted:

10 February 2017

Available Online:

10 March 2017
Despite this, very little information's available about existence of medicinal plants on the typical ravine flora. The present study attempted to explore the diversity and distribution of medicinal plant flora in the Yamuna ravines of Agra (U.P) and Chambal ravines of Kota district (Rajasthan). An account of 63 species belongs to 37 families were observed in the rehabilitated ravine areas at Agra. The documented plants were categorized according to their life form viz., trees $(34.92 \%)$, shrubs $(26.98 \%)$, herbs $(23.8 \%)$, climbers $(11.15 \%)$ and grasses $(3.18 \%)$ were found in the representative blocks. The present study reveals that the distributions of species were mainly belong to the families of Euphorbiaceae, Apocynaceae, Solanaceae and Caesalpiniaceae. At Chambal ravines, 106 species observed and it represents 54 families of plant kingdom with dominant families of Euphorbiaceae, Fabaceae, Asteraceae, Solanaceae and Amaranthaceae. Documented plants were categorized according to their life form viz., herbs (42.5\%), trees $(23.6 \%)$, shrubs $(21.6 \%)$, climbers $(10.4 \%)$ and grasses $(2 \%)$ were found in the representative blocks. It directly indicates rich plant biodiversity of Chambal ravines over Yamuna ravines. The documented indigenous plant species naturally have high drought tolerance capacity and ability to grow under harsh environment. The maximum revival of native flora in these rehabilitated ravines through rehabilitation, protection and other soil conservation measures. Urgent attention towards documentation, conservation, sustainable utilization and awareness creation are needed to protect indigenous medicinal flora by appropriate insitu and ex-situ conservation measures.

\section{Introduction}

Water is a critical element for reclamation of degraded lands for sustainable biomass production, ultimately leading to a better quality of life and environmental conditions. Degraded non arable lands cover vast tract in the country and are major source for 
supplying fuel, fodder and timber and other minor products to the population. The productivity of these lands is poor. Ravine lands are one of highly degraded dry land ecosystem associated with several ecological and environmental constraints for vegetation growth due to vicarious climate, poor soil fertility, low soil moisture, extreme variation in temperature and heavy biotic pressure. There are about 3.97 million hectors of ravine lands in India. In Uttar Pradesh alone, 1.23 million hectare $(14.5 \%)$ of land is under ravines which are found along the bank of river Yamuna and Chambal along with its tributaries. The severity of water erosion is found at the peak along the banks of Yamuna and Chambal Rivers in the districts of Agra, Etawah, Kanpur and Fetehpur etc., where terrain has completely deformed into ravines. The hot, semi arid ravenous tracts of the indoGangetic region posses very harsh climatic conditions like low and erratic rainfall and high summer temperature. This vast tract of existing ravine lands in northwestern part of India is possessing potential threat to nearby productive lands because of over exploitation and poor management. The ravines are extending at the rate of 8 to $9 \mathrm{~m}$ per annum with average soil loss of more than 17 tons per ha per year. The ravine lands are subjected to various forms of natural as well as anthropogenic forms of land degradation. Vegetation in this region suffers from a variety of unfavorable condition such as nutrient deficiency, moisture stress and biotic interference. Therefore, there is an urgent need to detain these problems and protect both the arable and non-arable land from further degradation. Situation specific costeffective viable technologies and dissemination of suitable technologies for reclamation and productive utilization of ravine lands in India are highly essential for arresting ravine extension, reclamation of ravine lands and improving production from the rain fed production systems of ravenous regions. Through rehabilitation and protection measures are control of erosion, reduce runoff (check dams, spill ways), improve in-situ soil-moisture conservation (trenches), arrest land degradation by planting trees and grasses and conserve natural resources.

Already, India has been traditionally known as a treasure house of high value medicinal plants used in both the local folk health traditions and in the Indian Systems of Medicine. The continuous illicit exploitation of several medicinal plant species from the wild and substantial loss of their habitats have resulted in population decline of many high value medicinal plant species over the years from different parts of India. There are many other potential causes of rarity in medicinal plant species, such as habitat specificity, narrow range of distribution, land use disturbances, introduction of non-natives, habitat alteration, climatic changes, heavy livestock grazing, explosion of human population, fragmentation and degradation of population, population bottleneck, and genetic drift. Additionally, natural enemies (i.e., pathogens, herbivores, and seed predators) could substantially limit the abundance of rare medicinal plant species in any given area (Bevill et al., 1999 ) An estimated 4,000 to 10,000 species of medicinal plants face potential local, national, regional or global extinction, with subsequent serious consequences for livelihoods, economies and health care systems (Dhyani and Kala, 2005). The medicinal plant wealth of Indian forests is declining constantly over the years (Hall and Bawa, 1993). However, even as concerns about fast depletion of this resource are being voiced, the degradation continues at even faster pace. Comprehensive documentation of the diversity of medicinal plants is not available and their conservation status is not known. According to an estimate, the quantity of export of Ayurvedic products 
produced in India has tripled between last two financial years. The demand of Indian medicinal plants has increased over the years in the international market.

The World Health Organization (WHO) has estimated the demand for medicinal plants is approximately US $\$ 14$ billion per year (Sharma, 2004). The demand for medicinal plant-based raw materials is growing at the rate of 15 to $25 \%$ annually, and according to an estimate of $\mathrm{WHO}$; the demand for medicinal plants is likely to increase more than US \$5 trillion in 2050. In India, the medicinal plant-related trade is estimated to be approximately US $\$ 1$ billion per year (Joshi et al., 2004).

Ravine ecosystems are highly dynamic and completely deformatted terrain landscape. In these regions, Indigenous plant species are playing significant role in environmental rehabilitation because of their exultant survival and high adaptation to local conditions. To meet out the demand of medicinal plants at international market we should use degraded lands of the country, this practice will help to save the crop land from overburden and different researches explain that the cultivation of various medicinal plants helps to reclaim the degraded lands. Despite this importance, very little information exits about medicinal plants on ravine flora in particular. Publications on the traditional knowledge of use of indigenous resources by local people are meager from this region as well as there is a lack information about diversity and distribution medicinal plants in the present study area. Keeping this view, a study has conducted to document the indigenous medicinal plant diversity, use, and management of these plants in the rehabilitated Yamuna ravines (Agra district of Uttar Pradesh) and Chambal Ravines (Kota district of Rajasthan).

\section{Materials and Methods}

Yamuna Ravine at Agra District - Uttar Pradesh, India

An intensive survey was conducted at 85 ha of ravine land area which it is located inside our ICAR-IISWC, Research farm at Chhalesar in Agra district and it is core part of typical Yamuna ravine. The study site is located at $23^{0} 52^{\prime}$ to $31^{0} 28^{\prime} \mathrm{N}$ latitudes and $77^{0} 06^{\prime}$ to $84^{0} 37^{\prime}$ E longitudes and $169 \mathrm{~m}$ above mean sea level with high terrain undulated topography. It has humid subtropical climate with high variation between summer and winter temperatures. Summers are long, from early April till October, with the monsoon season in between. Cold waves from the Himalayan region dip temperatures across the city in the winter from December to February. The average temperature is $32^{\circ} \mathrm{C}-47^{\circ} \mathrm{C}$ in summer; $10^{\circ} \mathrm{C}-15^{\circ} \mathrm{C}$ in the winter. The average annual rainfall is 550 $\mathrm{mm}$. Fog is common in winter while hot dry winds called loo blow in summer. Soils are generally old alluvial deposits of the middle Gangetic plain.

\section{Chambal Ravine at Kota District - Rajasthan, India}

The study area is located in Kota district of south-eastern Rajasthan (Latitude $25^{\circ} 13^{\prime} 29^{\prime \prime}$ to $25^{\circ} 14^{\prime} 18^{\prime \prime} \mathrm{N}$; Longitude $75^{\circ} 52^{\prime} 18^{\prime \prime}$ to $75^{\circ} 52^{\prime} 44^{\prime \prime}$ E). Climate of this region is hot semi-arid with the mean annual rainfall of $748 \mathrm{~mm}$. The study was conducted during 2015 at research farm of ICAR-IISWC, Research Centre, Kota. The research farm comprises of two distinct landscapes, the agricultural table lands (34 ha) and ravenous lands (34 ha) adjoining Chambal river. Soils of the research farm are classified under Kota series. These soils are deep to very deep soils occurring on flat gently sloping land with less than $2 \%$ slope. 
The CaCO3 layer generally occurs below $100 \mathrm{~cm}$. Soils are dominantly fine textured (>35\% clay) belonging to hyperthermic family of Typic chromusterts. Precipitation from June and September is nearly $80 \%$ of the mean annual rainfall $(516 \mathrm{~mm})$ and remaining $20 \%$ falls in winter season. Overall climate is moderate. Frost is common during winter season. Mean of minimum monthly temperature ranges from $4.7^{\circ} \mathrm{C}$ (Jan) to $24.2^{\circ} \mathrm{C}$ (Jul) and mean of maximum monthly temperature ranged from $21.2^{\circ} \mathrm{C}$ (Jan) to $33.10^{\circ} \mathrm{C}$ (Jul) in the year 2015. Kota district is situated in South of Rajasthan at latitude $30^{\circ} 39.125^{\prime} \mathrm{N}$ and longitude $78^{\circ} 31.156^{\prime} \mathrm{E}$. and is located along the eastern bank of the Chambal river, covering an area of approximately 521324 hectare $\left(12,436 \mathrm{~km}^{2}\right)$ and that is 3.63 per cent of the Rajasthan State. Out of which, area of forests is 125379 hectare, nonagriculture land is 60021 hectare and cultivable barren land is 23011 hectare. The Chambal River is natural boundary of Kota district that separates Kota from neighboring Sawai Madhopur, Tonk and Bundi districts by forming the natural district boundary. The repeated field surveys were conducted in the randomly selected sample plots $(10 \mathrm{~m}$ X 10 $\mathrm{m})$ to document the floral diversity. Observations were made on the morphological features and habitats of each medicinal plant species in the field. A transect survey and personal observation was conducted to know and understand the ecological indication and distribution of medicinal plants diversity in protected and rehabilitated areas of Yamuna ravines of Agra region. All the information about the sampled plants species were categorized into herbs, shrubs and trees. Ethnomedicinal uses of the plants were collected with help of well experienced traditional healer at two different sites and information were cross checked by relevant literature available in the library of the centre as well as online resources. Tables 1 and 2 consist of enlisted medicinal plants and their uses in the following sequences: common name, botanical name, family, habit, economic part and medicinal uses.

\section{Results and Discussion}

This paper enlisted 63 medicinal plants belong to 37 families, which are used as a folk medicine for treatment various ailments or disease to humans beings and domestic animals by local and common people in this region. The identified medicinal plants were comprised of mainly trees, shrubs, climbers and herbs. The mainly trees accounts $34.92 \%$ followed by shrubs $(26.98 \%)$, herbs $(23.81 \%)$ and climbers $(11.15 \%)$ in the whole study site (Figs. 1 and 2). The present study reveals that the majority of species were belonging to the families of Euphorbiaceae, Apocynaceae, Solanaceae and Cesalpinaceae. The identified /documented indigenous plant species have high drought tolerant capacity and ability to grow under harsh environment. Sustainable management of rehabilitated Yamuna ravines with proper protection definitely enhances the species richness and conservation biodiversity through vegetation cover induced microclimates modification. But rehabilitated ravine lands have considerable abundant diversity of medicinal plants compare unprotected ravine areas. The documented medicinal plants were categorized according to habit wise and their distribution viz., grasses $(3.18 \%)$ herbs $(23.8$ $\%)$, climbers (11.15\%), shrubs (26.98\%) and trees $(34.92 \%)$ were found in the sample plots (Fig. 2). The valley beds of ravines are occupied dense vegetative cover compared to slope and upper part of ravine lands. This may be due to more availability of soil moisture in the valley beds during monsoon and post monsoon seasons. Archana et al., (2007) documented and 
reported that a rich diversity medicinal plant resources and their folk uses from Banaras Hindu University in varanasi, Uttar Pradesh. Other studies conducted in Chandauli district of Uttar Pradesh showed similar kind trend of emphasizing medicinal diversity and ethnomedicinal uses (Singh and Singh, 2009).

The plants part used for medicines is differed from plant to plant. The mode/ formulation of intake includes plants applied as a paste, powder, decoction, extracts and juices and other applied as oil, smoke and chew. From this study at Yamuna ravine areas, leaf is most frequently used plant part which accounts $28 \%$ followed by root (20 $\%)$, Fruit (14\%), Seed (11\%), whole plant $(9 \%)$, bark $(8 \%)$, flower $(6 \%)$ and Gum (4\%) (Fig. 3). From this study at Chambal ravine areas, leaf is most frequently used plant part which accounts $38 \%$ followed by root $(23 \%)$, Fruit (16\%), Seed (16\%), whole plant (9\%), bark (8\%), Latex (4\%) and Gum (3\%) (Fig. 3).

The ethno-medical uses and information were also collected from traditional healers and local dwellers (elder people) of sample region. Crushing, homogenizing with ingredients and chewing were the commonly used forms of herbal preparation. Drinking, smoke inhalation and strap and hold on were the most frequently used methods of application. During the field visit the survey of data collection was made in different places i.e. waste lands, barren lands play ground, road side and agricultural fields. The current over-exploitation and soil compaction due to climatic and biotic factors seems to limit the ability of some species to propagate. There is no considerable diversity of medicinal plants in unprotected area and other open areas during rainy season also due to heavy biotic pressure viz., grazing and felling and it is a considered as a serious problem in ravine lands. This clearly shows the diversity and distribution pattern medicinal plants in rehabilitated areas through effective protection efforts. Majority of the identified medicinal plants play ecological roles by protecting soils from erosion through reducing erosive forces of the rain drop and through reducing velocity of run-off water. Some of these plants have also cultural and economic values, means they are used to make stool (bench), bed, milk container, butter container and other culturally used home furniture. In addition large trees like Ficus spp and Neem have social and economic value, used as shed during community meeting, as fodder for animals (especially for goats and camels), for house and fence constructions. Most trees and shrubs of those medicinal plants are commonly used for fuel wood. Most of the medicinal plants had no market value. This could be explained by various reasons. It was observed that few medicinal plants such as Aloe vera, Ber, Neem and Bael, had market value. However their market price was not still attractive. They were supplied to the market in different forms, but the most common parts sold in the market were leaves, roots, seeds and fruits. The present study revealed that the rehabilitated ravine lands have rich diversity of medicinal plants as compared to outside unprotected ravines. Therefore, there is immediate need to conserve these important plant species for sustainable uses for the future. Efforts should be taken to start sustainable cultivation and harvesting programs in the ravine regions.

This study reveals that the majority of species were belonging to the families of Euphorbiaceae, Apocynaceae, Solanaceae and Cesalpinaceae. 
Table.1 List of medicinal plants distributed in the rehabilitated Yamuna Ravines at Agra, Uttar Pradesh

\begin{tabular}{|c|c|c|c|c|c|c|}
\hline $\begin{array}{l}\text { Sl. } \\
\text { No }\end{array}$ & Botanical Name & $\begin{array}{l}\text { Local } \\
\text { Name }\end{array}$ & Family & Habit & $\begin{array}{l}\text { Part used \& } \\
\text { formulation }\end{array}$ & Medicinal use \\
\hline 1. & Abutilan indicum & Kanghil & Malvaceae & Herb & Leaf extract & Itching, wound healing \\
\hline 2. & Acacia catechu & Khair & Fabaceae & Tree & $\begin{array}{ll}\text { Bark } \\
\text { decoction }\end{array} \quad$ root & Arthritis \\
\hline 3. & Acacia nilotica & Babool & Mimosaceae & Tree & Bark, gum & Burning sensation \\
\hline 4. & Acalypa indica & Chauriya & Euphorbiaceae & Herb & Leaf paste & Wound healing \\
\hline 5. & $\begin{array}{l}\text { Achryranthes } \\
\text { aspera }\end{array}$ & Chirchita & Amaranthaceae & Shrub & Whole plant & Tuberculosis \\
\hline 6. & Adhatoda vassica & Adathoda & Acanthaceae & Shrub & Leaf paste & Piles \\
\hline 7. & Aegle marmelos & Beal & Rutaceae & Tree & Fruit and leaves & Sunstroke, dysentery \\
\hline 8. & Aerva lanata & Geduakichal & Amarnthaceae & Herb & Root paste & Headache \\
\hline 9. & Ailanthus excelsa & Anjan & Simaroubaceae & Tree & Leaf \& bark paste & Joint pain \& leprosy \\
\hline 10. & Albizia lebbeck & Siris & Fabaceae & Tree & Seed paste & Snake bite \\
\hline 11. & Aloe vera & Gwar patha & Liliaceae & Herb & Dried leaf decoction & $\begin{array}{l}\text { Easy and normal } \\
\text { delivery }\end{array}$ \\
\hline 12. & $\begin{array}{l}\text { Andrograpis } \\
\text { paniculata }\end{array}$ & Kalmegh & Acanthaceae & Herb & Whole plant & Snake bite \\
\hline 13. & $\begin{array}{l}\text { Argemone } \\
\text { mexicana }\end{array}$ & $\begin{array}{l}\text { Prickly } \\
\text { poppy }\end{array}$ & Papaveraceae & Herb & Root paste & Skin disease \\
\hline 14. & $\begin{array}{l}\text { Asparagus } \\
\text { racemosus }\end{array}$ & Satawar & Liliaceae & Climber & Dried roots & $\begin{array}{l}\text { Increase lactation } \\
\text { (cattle) }\end{array}$ \\
\hline 15. & Azadirachta indica & Neem & Meliaceae & Tree & All parts paste & $\begin{array}{l}\text { Skin disease \& blood } \\
\text { purifier }\end{array}$ \\
\hline 16. & $\begin{array}{l}\text { Balanites } \\
\text { agyaptica }\end{array}$ & Hingot & Balanitaceae & Tree & Fruit extract & Fever, deworming \\
\hline 17. & Bauhinia varigata & Kachnar & Caesalpiniaceae & Tree & Root dection & Reducing corpulence \\
\hline 18. & Butea monosperma & Palash & Papilionaceae & Tree & root \& bark decoction & Dysentery control \\
\hline 19. & Calotropis procera & Madar & Asclepiadaceae & Shrub & Root paste, latex & Snake bite, toothache \\
\hline 20. & Capparis decidua & Karil & Cappariaceae & Shrub & Leaves, fruits & Dysentery \\
\hline 21. & Carrisa carandus & Karonda & Cappariaceae & Shrub & fruit & $\begin{array}{l}\text { Dysentery and } \\
\text { diarrhoria }\end{array}$ \\
\hline 22. & Cassia fistula & Amaltas & Caesalpiniaceae & Tree & Fruits and seeds & Dysentery(cattle) \\
\hline 23. & Cassia tora & Chakora & Fabaceae & Herb & Root paste & Deworming in children \\
\hline 24. & $\begin{array}{l}\text { Catharanthus } \\
\text { roseus }\end{array}$ & Sadabahar & Apocynaceae & Shrub & seed and leaf extract & Honey bee bite \\
\hline 25. & Clitoria ternatea & Aparajita & Papilionaceae & Climber & Root powder & $\begin{array}{l}\text { Chest pain and insect } \\
\text { bite }\end{array}$ \\
\hline 26. & $\begin{array}{l}\text { Commiphora } \\
\text { mukul }\end{array}$ & Guggal & Burseraceae & Herb & Gum decoction & Scorpion bite \\
\hline 27. & Cordial myxa & Lasoda & Boraginaceae & Tree & Bark powder & Cure piles \\
\hline 28. & Cynodan dactylon & Doob grass & Graminae & Grass & Whole plant & $\begin{array}{l}\text { Menstrual disorders } \\
\text { and fatness reduction }\end{array}$ \\
\hline 29. & Datura metal & $\begin{array}{l}\text { Kali } \\
\text { Dhatura }\end{array}$ & Solanaceae & Herb & Leaf paste & Cure pimples \\
\hline 30. & Dendrocalamus & Bans & Poaceae & Tree & Leaves, seeds, bark & Wound healing, stop \\
\hline
\end{tabular}




\begin{tabular}{|c|c|c|c|c|c|c|}
\hline & strictus & & & & juice & bleeding \\
\hline 31. & Emblica officinalis & Aonla & Euphorbiaceae & Tree & Fruits & vomiting \\
\hline 32. & $\begin{array}{l}\text { Euphorbia } \\
\text { prostrata }\end{array}$ & Dudhi & Euphorbiaceae & Climber & Root powder & Milk secretion \\
\hline 33. & Grewia asiatica & Phalsa & Tiliaceae & Shrub & Root paste & Back pain \\
\hline 34. & $\begin{array}{l}\text { Hemidesmus } \\
\text { indicus }\end{array}$ & Gurmar & Asclepediaceae & climber & Root paste & Blood purifier \\
\hline 35. & Ipomea cornea & Ipomea & Convolvulaceae & climber & Root & Increase Lactation \\
\hline 36. & Jatropha curcas & Ratanjot & Euphorbiaceae & Shrub & Seeds, oil and latex & Mouth ulcer \\
\hline 37. & Lowsonia inermis & Mehandi & Lytheraceae & Tree & Leaves, fruit paste & $\begin{array}{l}\text { Body cooling, hair } \\
\text { dyeing }\end{array}$ \\
\hline 38. & Madhuca longifilia & Mahua & Sapotaceae & Tree & $\begin{array}{l}\text { Leaves, flower and } \\
\text { seeds }\end{array}$ & Stomach pain \\
\hline 39. & Melia azadirach & Bakayan & Meliaceae & Tree & Leaf \& flower paste & Pregnancy weakness \\
\hline 40. & Mimosa pudica & Laajivanthi & Mimosaceae & Herb & Leaf paste & Ear pain \& headache \\
\hline 41. & Moringa oleifera & Sehjan & Moringaceae & Tree & Leaf, fruit, gum & $\begin{array}{l}\text { Vomiting \& } \\
\text { constipation }\end{array}$ \\
\hline 42. & Morus alba & Shahtut & Moraceae & Tree & Root decoction & Dysentery \\
\hline 43. & Nerium indicum & Kaner & Apocynaceae & Shrub & Root paste & Skin disease \\
\hline 44. & $\begin{array}{l}\text { Ocimum } \\
\text { grantissimum }\end{array}$ & Van tulsi & Lamiaceae & Herb & Seed paste & Fever, dysentery \\
\hline 45. & Ocimum sanctum & Tulsi & Lamiaceae & Herb & Seed paste & Eye burning, dysentery \\
\hline 46. & Phyllanthus niruri & Bhui anola & Euphorbiaceae & Shrub & Whole plant extract & Jaundice \\
\hline 47. & Pongamia pinnta & Karanj & Leguminosae & Tree & $\begin{array}{l}\text { Seeds oil and root } \\
\text { bark paste }\end{array}$ & Mouth ulcer \\
\hline 48. & Punica grantum & Anar & Punicaceae & Shrub & Flower \& fruit paste & Toothache, dysentery \\
\hline 49. & $\begin{array}{l}\text { Putranjiva } \\
\text { roxburghii }\end{array}$ & Putranjiva & Euphorbiaceae & Tree & Leaf extract & $\begin{array}{l}\text { Fever, burning } \\
\text { sensation }\end{array}$ \\
\hline 50. & Ricinus communis & Caster & Euphorbiaceae & Shrub & Root powder & Pregnancy weakness \\
\hline 51. & $\begin{array}{l}\text { Salmanelia } \\
\text { malabarica }\end{array}$ & Semal & Bombacaceae & Tree & Flower paste & For easy delivery \\
\hline 52. & Sida cordifolia & Kharenti & Malvaceae & Shrub & Whole herb & Rheumatism \\
\hline 53. & Solanum nigrum & Makoy & Solanaceae & Herb & Root decoction & Body pain externally \\
\hline 54. & Syzygium cumini & Jamun & Myrtaceae & Tree & Fruits and leaves & Diabetics \\
\hline 55. & Tamarindus indica & Imlli & Caesalpiiaceae & Tree & Leaf extract & $\begin{array}{l}\text { Constipation blood } \\
\text { purifier }\end{array}$ \\
\hline 56. & Teprosia purpurea & Sapunkha & Papilionaceae & Herb & Whole plant powder & Stomach problem \\
\hline 57. & Terminalia arjun & Arjun & Combretaceae & Tree & Leaf paste & Urinary infection \\
\hline 58. & $\begin{array}{l}\text { Tinospora } \\
\text { cordifolia }\end{array}$ & Giloy & Menispermaceae & Climber & Fruit paste & Blood purifier \\
\hline 59. & Tridex procumbens & Nahtoota & Asteraceae & Herb & Leaf extract & Rheumatism, ear pain \\
\hline 60. & Vitex negundo & Nirgundi & Verbanaceae & Shrub & Twig \& Leaf paste & $\begin{array}{l}\text { Toothache, cold \& } \\
\text { cough }\end{array}$ \\
\hline 61. & $\begin{array}{l}\text { Withania } \\
\text { somnifera }\end{array}$ & Aswagandh & Solanaceae & Shrub & Leaf powder & Reduce Fatness \\
\hline 62. & Wrightia tictoria & Kudruku & Apocyanaceae & Tree & Bark extract & Piles problem \\
\hline 63. & Zizyphus jujube & Ber & Rhamnaceae & Shrub & Fruit pulp & $\begin{array}{l}\text { Health-tonic, } \\
\text { constipation }\end{array}$ \\
\hline
\end{tabular}


Table. 2 List of medicinal plants distributed in the rehabilitated Chambal Ravines at Kota district, Rajasthan, India

\begin{tabular}{|c|c|c|c|c|c|c|}
\hline $\begin{array}{l}\text { Sl. } \\
\text { No }\end{array}$ & Botanical Name & Local Name & Family & Habit & $\begin{array}{l}\text { Part used \& } \\
\text { formulation }\end{array}$ & Medicinal use \\
\hline 1. & Abrus precatorius & Chirmi & Fabaceae & Climber & Seed extract & $\begin{array}{l}\text { Abortifacient and } \\
\text { sedative }\end{array}$ \\
\hline 2. & Abutilan indicum & Kanghil & Malvaceae & Herb & Leaf extract & Itching, wound healing \\
\hline 3. & Acacia catechu & Khair & Fabaceae & Tree & Bark \& Root & Arthritis \\
\hline 4. & Acacia nilotica & Babool & Mimosaceae & Tree & Bark, gum & Burning sensation \\
\hline 5. & Acalypa indica & Chauriya & Euphorbiaceae & Herb & Leaf paste & Wound healing \\
\hline 6. & Achryranthes aspera & Chirchita & Amaranthaceae & Shrub & Whole plant & Tuberculosis \\
\hline 7. & Adhatoda zeylanica & Ardusa & Acanthaceae & Shrub & Leaf extract & cough, cold, headache \\
\hline 8. & Aegle marmelos & Beal & Rutaceae & Tree & Fruit and leaves & Sunstroke, dysentery \\
\hline 9. & Aerva lanata & Kali-Bui & Amaranthaceae & Herb & Root extract & Pneumonia and typhoid \\
\hline 10. & Ailanthus excelsa & Anjan & Simaroubaceae & Tree & $\begin{array}{lll}\begin{array}{l}\text { Leaf } \\
\text { paste }\end{array} & \text { bark } \\
\end{array}$ & Joint pain \& leprosy \\
\hline 11. & Albizia lebbeck & Siris & Fabaceae & Tree & Seed paste & Snake bite \\
\hline 12. & Aloe vera & Gwar patha & Liliaceae & Herb & Dried leaf & $\begin{array}{l}\text { Easy and normal } \\
\text { delivery }\end{array}$ \\
\hline 13. & Amaranthus caudatus & Chauli & Amaranthaceae & Herb & Green leafs & Constipation \\
\hline 14. & Amaranthus blitoides & Pigweed & Amaranthaceae & Herb & Green leafs & Vegetable for children \\
\hline 15. & Ammannia baccifera & Jal bhangro & Lythraceae & Herb & Leaf paste & Skin itching \\
\hline 16. & Andrograpis paniculata & Kalmegh & Acanthaceae & Herb & Whole plant & Snake bite \\
\hline 17. & Argemone mexicana & Prickly poppy & Papaveraceae & Herb & Root paste & Skin disease \\
\hline 18. & Asparangus racemosus & Satawari & Asparangaceae & Climber & Root powder & Peptic ulcers, Arthritis \\
\hline 19. & Asphodelus tenuifolius & Wild onion & $\begin{array}{l}\text { Xanthorrhoeace } \\
\text { ae }\end{array}$ & Herb & Leaf decoction & Kidney stone \\
\hline 20. & Azadirachta indica & Neem & Meliaceae & Tree & All parts paste & $\begin{array}{l}\text { Skin disease \& } \\
\text { dewarming }\end{array}$ \\
\hline 21. & Balanites agyaptica & Hingot & Balanitaceae & Tree & Fruit extract & Fever, deworming \\
\hline 22. & Bareria prionitis & Bajrandanti & Acanthaceae & Shrub & Leaf decoction & Tooth ache and pyorrhea \\
\hline 23. & Bauhinia varigata & Kachnar & Caesalpiniaceae & Tree & Root & Reducing corpulence \\
\hline 24. & Bergia suffruticosa & Ankh-Phorniki & Elatinaceae & Herb & Plant paste & Cure broken bone \\
\hline 25. & Boerhavia procumbens & Santhi & Nyctaginaceae & Herb & Root paste & Cure scorpion sting \\
\hline 26. & Butea monosperma & Palash & Papilionaceae & Tree & Root \& bark & Dysentery control \\
\hline 27. & $\begin{array}{l}\text { Calligonum } \\
\text { polygonoides }\end{array}$ & Phog & Polygonaceaee & Shrub & Plant extract & $\begin{array}{l}\text { Typhoid, urinary } \\
\text { problems }\end{array}$ \\
\hline 28. & Calotropis procera & Aakda & Asclepiadaceae & Shrub & Root paste, latex & Snake bite, toothache \\
\hline 29. & Capparis decidua & Karil & Cappariaceae & Shrub & Leaves \& fruits & Dysentery \\
\hline 30. & Carrisa carandus & Karonda & Cappariaceae & Shrub & fruit & Dysentery and Diarrhea \\
\hline 31. & Cassia fistula & Amaltas & Caesalpiniaceae & Tree & Fruits and seeds & Dysentery (cattle) \\
\hline 32. & Cassia tora & Phunwad & Caesalpinaceae & Shrub & Leaf decoction & toothache Fever \\
\hline 33. & Catharanthus roseus & Sadabahar & Apocynaceae & Shrub & seed and leaf & Honey bee bite \\
\hline 34. & Chenopodium album & Chilva & Chenopodiaceae & Herb & Leafy vegetable & Leaf extract for worms \\
\hline 35. & Citrullus colocynthis & Gar-tumba & Cucurbitaceae & Climber & Roasted fruits & $\begin{array}{l}\text { Digestive } \\
\text { (cattle) }\end{array}$ \\
\hline 36. & Cleome gynandra & Karalia & Cleomaceae & Herb & Green leafs & Skin diseases, earache \\
\hline
\end{tabular}




\begin{tabular}{|c|c|c|c|c|c|c|}
\hline 37. & Cleome viscosa & Singali & Cleomaceae & Herb & Seed powder & Cure bleeding piles \\
\hline 38. & Clitoria ternatea & Aparajita & Papilionaceae & Climber & Root powder & $\begin{array}{l}\text { Chest pain and insect } \\
\text { bite }\end{array}$ \\
\hline 39. & Coculus hirsutus & Bajar -bel & $\begin{array}{l}\text { Menispermacea } \\
\mathrm{e}\end{array}$ & Climber & Leaf and root & Skin disease \\
\hline 40. & Commiphora mukul & Guggal & Burseraceae & Herb & Gum decoction & Scorpion bite \\
\hline 41. & Corbichonia decumbens & Patharchatti & Molluginaceae & Herb & Leaf juices & Treat gonorrhea \\
\hline 42. & Cordial myxa & Lasoda & Boraginaceae & Tree & Bark powder & Cure piles \\
\hline 43. & Cynodan dactylon & Doob grass & Graminae & Grass & Whole plant & Menstrual disorders \\
\hline 44. & Datura innoxia & Kali Dhatura & Solanaceae & Herb & Leaf paste & Cure pimples \\
\hline 45. & Dendrocalamus strictus & Bamboo & Poaceae & Tree & Leaves \& bark & Stop bleeding \\
\hline 46. & Dicoma tomentosa & Choloharnach & Asteraceae & Herb & $\begin{array}{ll}\text { Root } & \text { and } \\
\text { branches }\end{array}$ & Cure pyorrhea \\
\hline 47. & Emblica officinalis & Aonla & Euphorbiaceae & Tree & Fruits & vomiting \\
\hline 48. & Eucalyptus tereticornis & Red gum & Myrtaceae & Tree & Leaf extract & Headache, body pain \\
\hline 49. & Euphorbia hirsuta & Dudhi & Euphorbiaceae & Herb & Root paste & Increase lactation \\
\hline 50. & Euphorbia nerifolia & Danda -thor & Euphorbiaceae & Shrub & Latex & Asthma, leprosy \\
\hline 51. & Euphorbia prostrata & Dudhi & Euphorbiaceae & Climber & Root powder & Milk secretion \\
\hline 52. & Glinus lotoides & Gandhi-buti & Molluginaceae & Herb & Plant juices & $\begin{array}{l}\text { weakness } \\
\text { indigestion }\end{array}$ \\
\hline 53. & Grewia asiatica & Phalsa & Tiliaceae & Shrub & Root paste & Back pain \\
\hline 54. & Hemidesmus indicus & Gurmar & Asclepediaceae & Climber & Root paste & Blood purifier \\
\hline 55. & Impatiens balasamina & Timadia & Balsaminaceae & Herb & Leaf extract & Wounds and swelling \\
\hline 56. & Ipomea cornea & Ipomea & Convolvulaceae & Climber & Root & Increase Lactation \\
\hline 57. & Jatropha curcas & Ratanjot & Euphorbiaceae & Shrub & $\begin{array}{l}\text { Seeds, oil and } \\
\text { latex }\end{array}$ & Mouth ulcer \\
\hline 58. & Lantana camera & Lantana & Verbanaceae & Shrub & Leaf Decoction & Tetanus, Malaria \\
\hline 59. & Leucas urticaefolia & Darkan & Laminaceae & Herb & Leaf and flower & Cold and cough \\
\hline 60. & Lowsonia inermis & Mehandi & Lytheraceae & Tree & $\begin{array}{l}\text { Leaves, fruit } \\
\text { paste }\end{array}$ & $\begin{array}{l}\text { Body cooling, hair } \\
\text { dyeing }\end{array}$ \\
\hline 61. & Madhuca longifilia & Mahua & Sapotaceae & Tree & flower \& fruit & Stomach pain \\
\hline 62. & Martynia annua & Bichtukando & Martynaceae & Shurb & Leaf paste & Treating rheumatism \\
\hline 63. & Melia azadirach & Bakayan & Meliaceae & Tree & $\begin{array}{l}\text { Leaf \& flower } \\
\text { paste }\end{array}$ & Pregnancy weakness \\
\hline 64. & Mimosa hamata & Alai & Mimosaceae & Shrub & Seed powder & Cure male impotency \\
\hline 65. & Mimosa pudica & Laajivanthi & Mimosaceae & Herb & Leaf paste & Ear pain \& headache \\
\hline 66. & Mollugo cervianana & Chirio ghas & Molluginaceae & Herb & leaf & Clean uterus \\
\hline 67. & Momordia foetida & khakoda & Cucurbitaceae & Climber & Leaf \& fruit & Cure Malaria, Snakebite \\
\hline 68. & Moringa oleifera & Sehjan & Moringaceae & Tree & Leaf, fruit, gum & Vomiting \& constipation \\
\hline 69. & Medicago sativa & Alfa-alfa & Fabaceae & Herb & Root decoction & Dysentery \\
\hline 70. & Mucuna pruriens & Kirmich & Fabaceae & Herb & Seed powder & Cure asthma \\
\hline 71. & Nerium indicum & Kaner & Apocynaceae & Shrub & Root paste & Skin disease \\
\hline 72. & Ocimum americanum & Bapchi & Laminaceae & Herb & Seed powder & Leucoderma and leprosy \\
\hline 73. & Ocimum grantissimum & Van tulsi & Lamiaceae & Herb & Seed paste & Fever, dysentery \\
\hline 74. & Ocimum sanctum & Tulsi & Lamiaceae & Herb & Seed paste & Malarial Fever \\
\hline 75. & Oxalis corniculata & Aaera & Oxalidaceae & Herb & Leaves & Piles, anemia \\
\hline 76. & Pedalium murex & Dakhni & Pedaliaceae & Herb & Plant extract & Health tonic \\
\hline 77. & Pergularia daemia & Milk weed & asclepiadaceae & Climber & leaves & Body pain \\
\hline 78. & Phyllanthus niruri & Bhui anola & Euphorbiaceae & Shrub & Whole & Jaundice \\
\hline
\end{tabular}


Int.J.Curr.Microbiol.App.Sci (2017) 6(3): 618-630

\begin{tabular}{|c|c|c|c|c|c|c|}
\hline & & & & & extract & \\
\hline 79. & Physalis angulata & Cap Berry & solanaceae & Herb & Leaves & Hemorrhage \\
\hline 80 . & Physalis minima & Chirpotan & solanaceae & Herb & fruits & Colic complaints, dropsy \\
\hline 81. & Polygonum plebeium & Lalbuti & Polygonaceae & Herb & Leaf extracts & $\begin{array}{ll}\text { Colic } & \text { complaints, } \\
\text { eczema }\end{array}$ \\
\hline 82. & Pongamia pinnta & Karanj & Leguminosae & Tree & $\begin{array}{l}\text { Seeds \& root } \\
\text { paste }\end{array}$ & Mouth ulcer \\
\hline 83. & Portulaca oleracea & Lunkia & portulaceae & Herb & Leaf extracts & Scurvy, liver diseases \\
\hline 84. & Punica grantum & Anar & Punicaceae & Shrub & Flower \& fruit & Toothache, dysentery \\
\hline 85. & Ricicnus communis & Castor & Euphorbiaceae & Shrub & Leaves & Eye diseases \\
\hline 86. & Sida cordifolia & Kharenti & Malvaceae & Shrub & Whole herb & Rheumatism \\
\hline 87. & Sida ovata & Desikharenti & Malvaceae & Herb & Seed powder & Cure Lumbago in winter \\
\hline 88. & Solanum nigrum & Makoy & Solanaceae & Herb & Root decoction & Body pain externally \\
\hline 89. & Solnaum suranttense & Pasarghatali & solanaceae & Herb & Leaf \& fruits & Skin diseases, cures piles \\
\hline 90. & Sonchus ankhali & Ankhali & Asteraceae & Herb & Leaf extract & $\begin{array}{l}\text { Cure live disease, } \\
\text { cirrhosis }\end{array}$ \\
\hline 91. & Sonchus asper & Kalijibi & Asteraceae & Herb & Plant extract & Increasing Lactation \\
\hline 92. & Sphaeranthus indicus & Mundi & Asteraceae & Herb & Root powder & Cure male impotency \\
\hline 93. & Syzygium cumini & Jamun & Myrtaceae & Tree & $\begin{array}{ll}\begin{array}{l}\text { Fruits } \\
\text { leaves }\end{array} & \text { and } \\
\end{array}$ & Diabetics \\
\hline 94. & Tamarindus indica & Imlli & Caesalpiiaceae & Tree & Leaf extract & $\begin{array}{l}\text { Constipation blood } \\
\text { purifier }\end{array}$ \\
\hline 95. & Tecomella undulata & Rohida & Bignonliaceae & Tree & Bark paste & $\begin{array}{l}\text { Cure eczema and } \\
\text { eruptions }\end{array}$ \\
\hline 96. & Tephrosia purpurea & Dhamaso & Fabaceae & Herb & Root powder & $\begin{array}{l}\text { Snake bite, blood } \\
\text { purifier }\end{array}$ \\
\hline 97. & Terminalia arjun & Arjun & Combretaceae & Tree & Leaf paste & Urinary infection \\
\hline 98. & Tinospora cordifolia & Giloy & $\begin{array}{l}\text { Menispermacea } \\
\mathrm{e}\end{array}$ & Climber & Fruit paste & Blood purifier \\
\hline 99. & Trianthema triquetra & Lutanki & Aizoaceae & Herb & Plant paste & $\begin{array}{ll}\text { Cure } & \text { rheumatism } \\
\text { swellings } & \end{array}$ \\
\hline 100. & Tridex procumbens & Nahtoota & Asteraceae & Herb & Leaf extract & Rheumatism, ear pain \\
\hline 101. & Vitex negundo & Sambhalu & Verbaceae & Shrub & Seed powder & $\begin{array}{ll}\text { Ladies } & \text { menstrual } \\
\text { problems } & \\
\end{array}$ \\
\hline 102. & Waltheria americana & Surli & Byttneriaceae & Tree & Root extract & Cure spermatorrhoea \\
\hline 103. & Withania somnifera & Aswagandh & Solanaceae & Shrub & Leaf powder & Reduce Fatness \\
\hline 104. & Wrightia tictoria & Kudruku & Apocyanaceae & Tree & Bark extract & Piles \\
\hline 105. & Xanthium indicum & Bichhu-butti & Asteraceae & Shrub & Fruit extract & Cure eczema and scabies \\
\hline 106. & Zizyphus mauritiana & Ber & Rhamnaceae & Tree & Fruit pulp & Constipation, dysentery \\
\hline
\end{tabular}


Fig.1 Map showing the two different ravine study sites

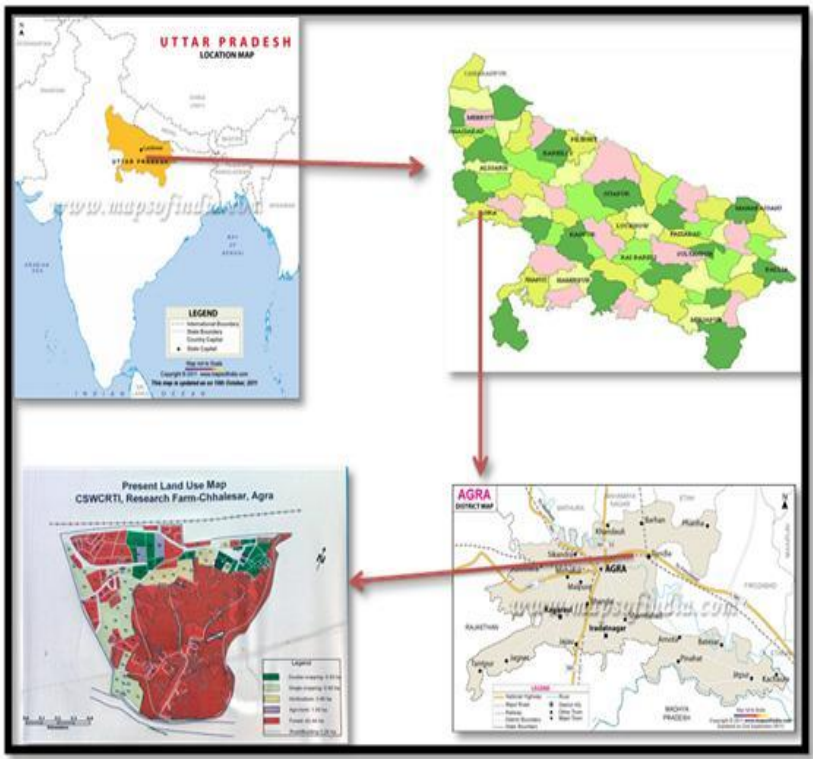

Yamuna ravine

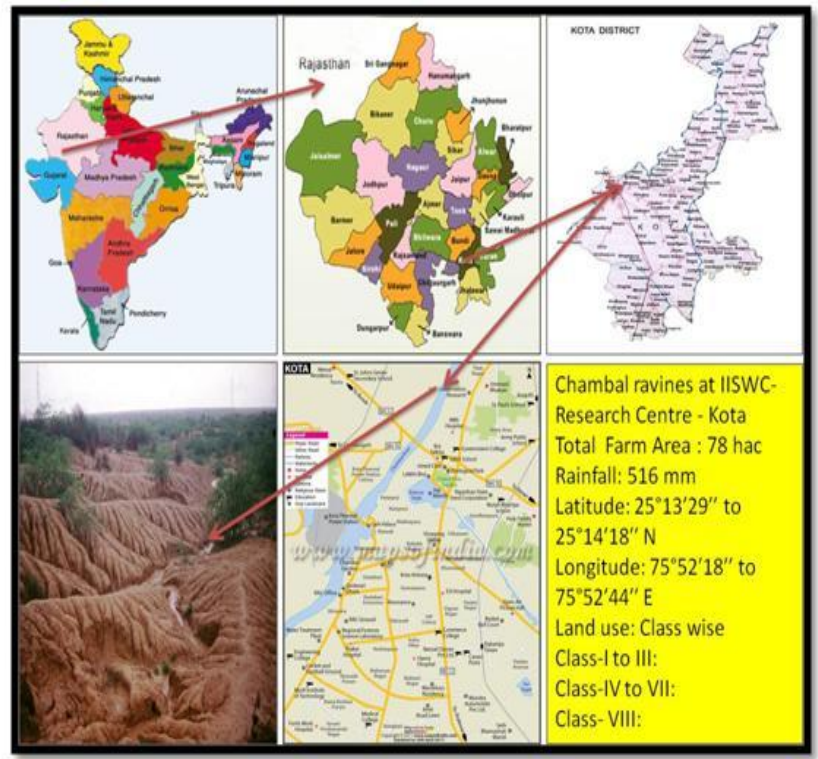

Chambal ravine

Fig.2 Habit wise distribution of medicinal plants

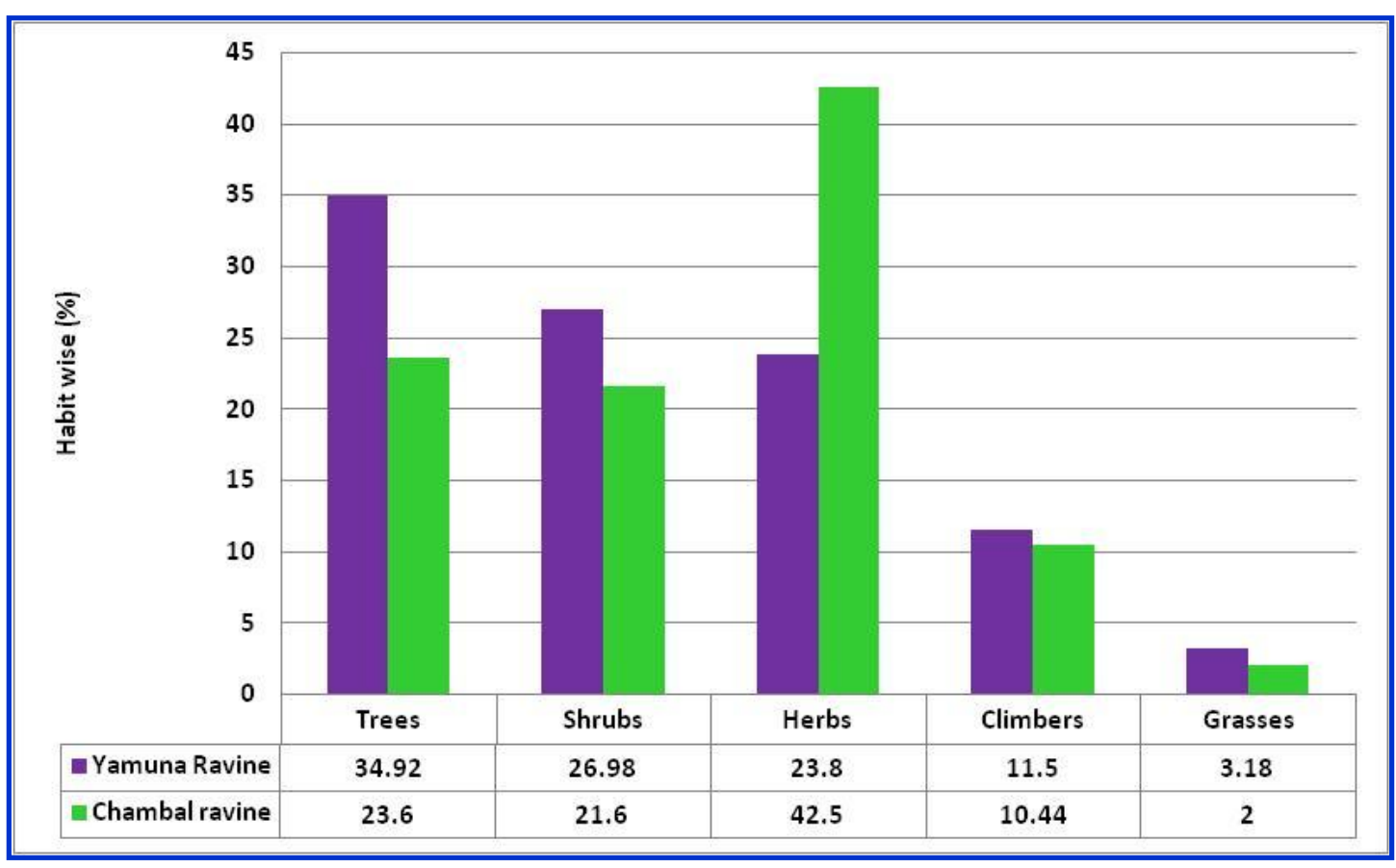


Fig.3 Proportion of plant parts used (\%) as a medicine

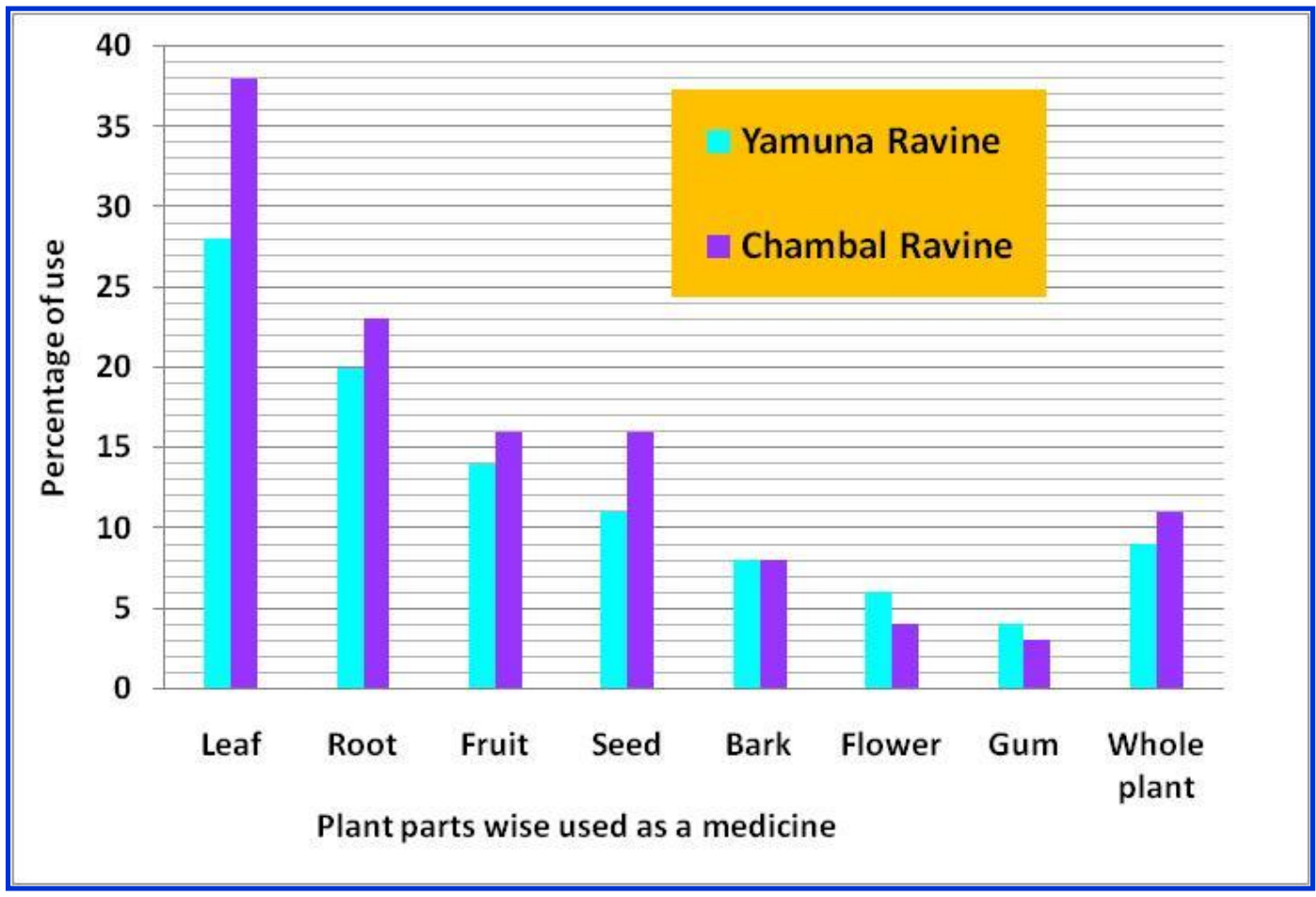

The identified /documented indigenous plant species have high drought tolerant capacity and ability to grow under harsh environment. Sustainable management of rehabilitated Yamuna ravines with proper protection definitely enhances the species richness and conservation biodiversity through vegetation cover induced microclimates modification. The preparations of medicines are from leaves, root, bark, fruit, flowers and seeds. The mode/ formulation of intake includes plants applied as a paste, powder, decoction, extracts and juices and other applied as oil, smoke and chew.

Indigenous knowledge and their uses have to be analysed to develop appropriate management measures. Due respect must be given to the indigenous botanical knowledge of the local / traditional practitioners to ensure equality in benefit sharing and increased participation in conservation. Therefore, awareness creation campaigns are timely needed to improve local community's knowledge on the importance and management of medicinal plants. In situ conservation has come to be widely regarded as the only viable and cost effective measure to allow the species to follow the natural evolutionary course in interaction with their habitat and within themselves.

The existing information on the medicinal plant diversity in the country is sketchy and lies scattered with various research institutes across the country, Whereas the existing information needs to be compiled, a comprehensive programme to document the diversity and current status of medicinal plants in the country needs to be initiated. Hence this study has taken to identified indigenous medicinal plants diversity in the rehabilitated Yamuna and Chambal ravines for further bio-chemical and genetic variability studies are a means to arrive at the conservation and commercial value through value addition of different populations of the species. 


\section{References}

Archana, K., Verma, Munesh Kumar and Rainer, W., Bussmann. 2007. Medicinal plants in an urban environment: the medicinal flora of Banaras Hindu University, Varanashi, Uttar Pradesh. J. Ethnobiol. Ethnomed., 3(8): 35 pp.

Bevill, R.L, S.M. Louda and L.M. Stanforth. 1999. Protection from natural enemies in managing rare plant species. Conservation Biol., 13: 1323-1331.

Dhyani, P.P. and C.P. Kala. 2005. Current research on medicinal plants: Five lesser known but valuable aspects. Curr. Sci., 88: pp335-340
Hall, P. and K. Bawa. 1993. Methods to assess the Impact of Extraction of Non-Timber Tropical Forest Products on Plant Populations. Economic Bot., 47: 234-247.

Joshi, K.P., D. Chavan, B. Warude and Patwardhan. 2004. Molecular markers in herbal drug technology. Curr. Sci., 87: pp159-165.

Sharma, A.B. 2004. Global Medicinal Plants Demand May Touch $\$ 5$ Trillion By 2050, Indian Express.

Singh, A. and Singh, P.K. 2009. An ethnobotanical study of medcinal plants in chanduali district of Uttar Pradesh in India. J. Ethnopharmocol., 121(2): 324-329.

\section{How to cite this article:}

Kala, S., H.R. Meena, I. Rashmi, M. Prabavathi, A.K. Singh and Singh, R.K. 2017. Status of Medicinal Plants Diversity and Distribution at Rehabilitated Yamuna and Chambal Ravine land Ecosystems in India. Int.J.Curr.Microbiol.App.Sci. 6(3): 618-630. doi: https://doi.org/10.20546/ijcmas.2017.603.072 